See discussions, stats, and author profiles for this publication at: https://www.researchgate.net/publication/320737111

The Role of the Rhizosphere and Microbes Associated with Hyperaccumulator Plants in Metal Accumulation

Chapter · January 2018

DOI: 10.1007/978-3-319-61899-9_9

CITATIONS

9

2 authors:

Emile Benizri

University of Lorraine

83 PUBLICATIONS 1,734 CITATIONS

SEE PROFILE
READS

443

Petra Kidd

Spanish National Research Council

99 PUBLICATIONS 2,462 CITATIONS

SEE PROFILE

Some of the authors of this publication are also working on these related projects:

Cultivation of Ni-hyperaccumulating Mediterranean plant species in ultramafic soils for phytomining View project

Project Microbial diversity of ultramafic soils View project 


\title{
The Role of the Rhizosphere and Microbes Associated with Hyperaccumulator Plants in Metal Accumulation
}

\author{
Emile Benizri and Petra S. Kidd
}

\begin{abstract}
Phytomining can be limited by low biomass productivity by plants or limited availability of soil metals. Ongoing research attempts to overcome these potential constraints and to make phytomining a successful commercial technique in the recovery of metals from polluted or naturally metal-rich soil by (hyper)accumulating plants. Recently, the benefits of combining phytoremediation with bioremediation, which consists in the use of beneficial microorganisms such as endophytes or rhizosphere bacteria and fungi, for metal removal from soils have been demonstrated. Metal-resistant microorganisms play an important role in enhancing plant survival and growth in these soils by alleviating metal toxicity and supplying nutrients. Furthermore, these beneficial microorganisms are able to enhance the metal bioavailability in the rhizosphere of plants. An increase in plant growth and metal uptake increases the effectiveness of phytoremediation processes coupled with bioremediation. Herein, we highlight the specificity of the rhizosphere and the critical roles in soil nutrient cycling and provision of ecosystem services that can be brought by rhizosphere microorganisms. We discuss how abiotic factors, such as the presence of metals in polluted sites or in naturally rich (ultramafic) soils modulate activities of soil microbial communities. Then we introduce the concept of microbe-assisted phytomining, and underline the role of plant-associated microorganisms in metal bioavailability and uptake by host plants that has attracted a growing interest over the last decade. Finally, we present various techniques, including phenotypic, genotypic, and metagenomic approaches, which allow for characterising soil microbial community structure and diversity in polluted or naturally metal-rich soils.
\end{abstract}

E. Benizri $(\bowtie)$

UMR 1120 Sols et Environnement - INRA, Université de Lorraine, Vandoeuvre-lès-Nancy 54518, France

e-mail: emile.benizri@univ-lorraine.fr

\section{P.S. Kidd}

Instituto de Investigaciones Agrobiológicas de Galicia (IIAG), Consejo Superior de Investigaciones Científicas (CSIC), Santiago de Compostela 15706, Spain 


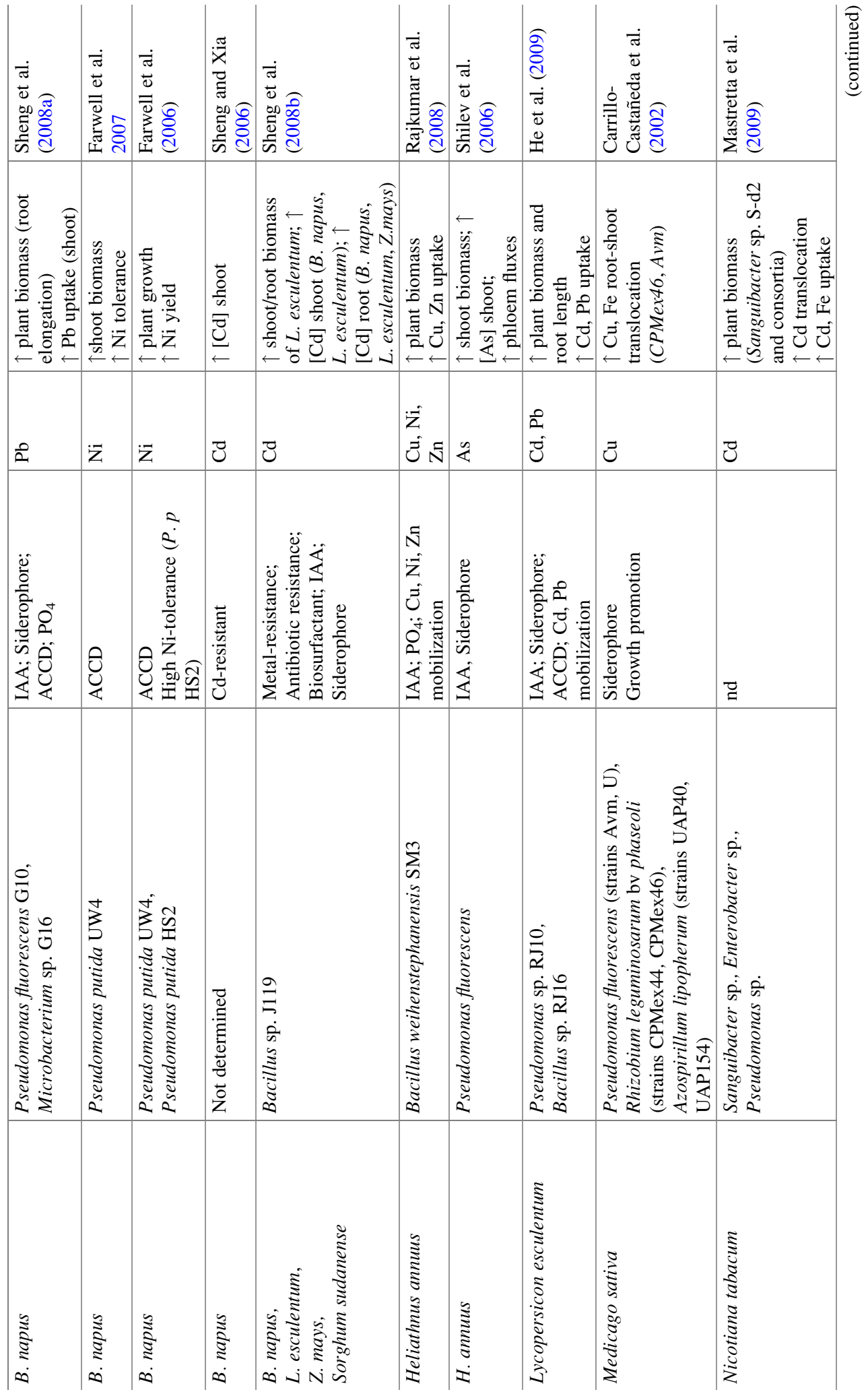




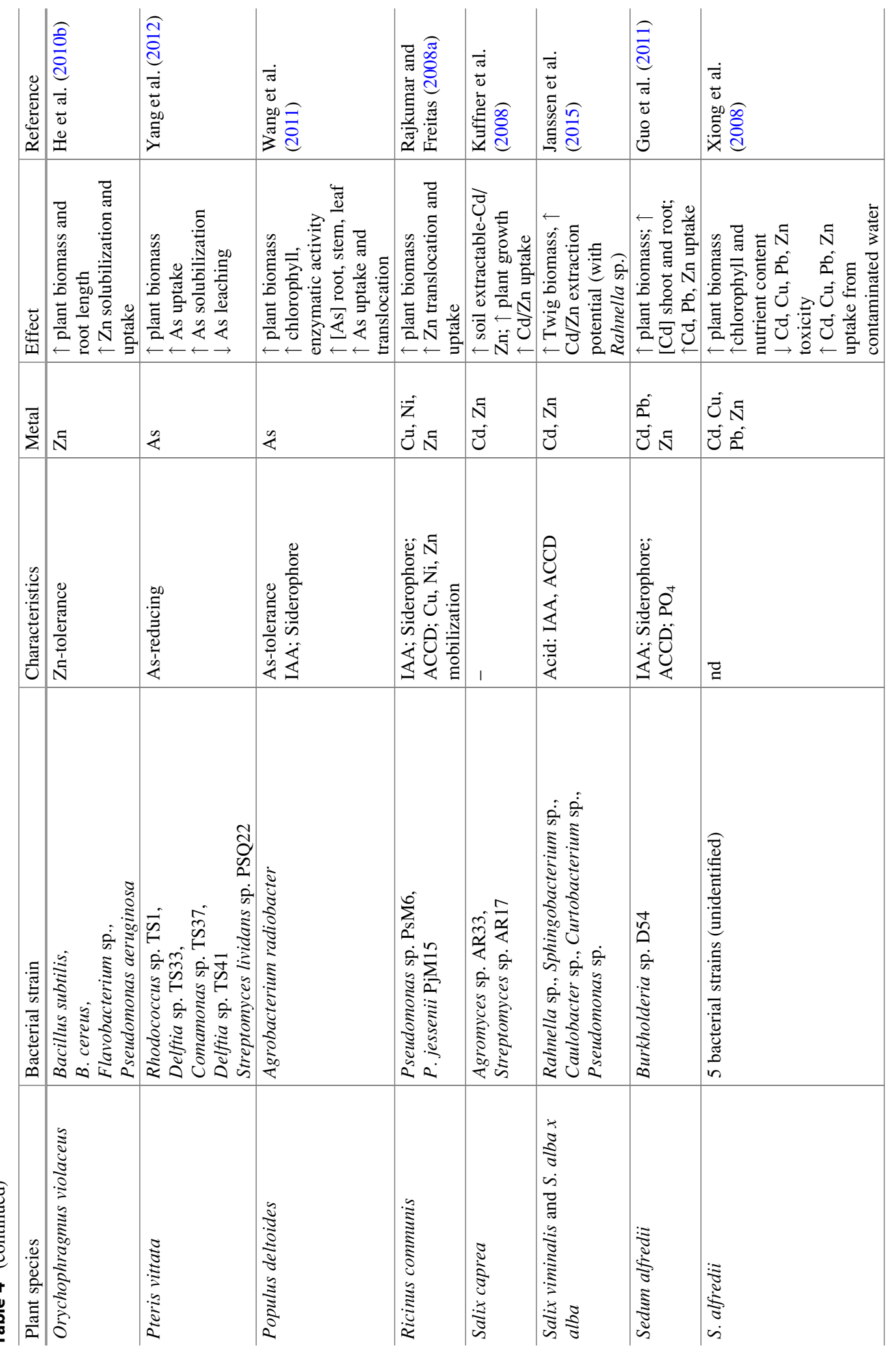




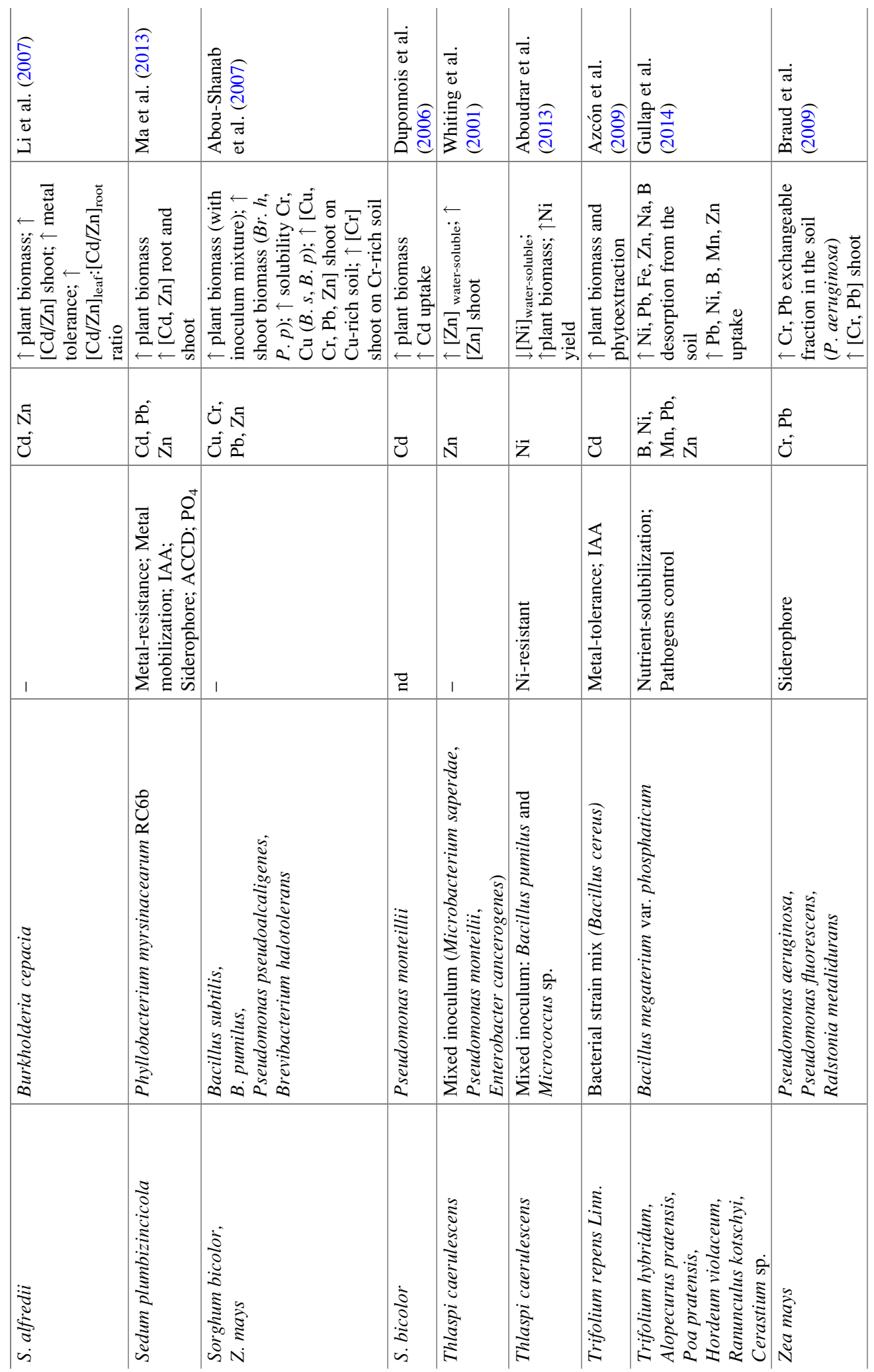


Durand et al. 2016; Álvarez-López et al. 2016a). Schlegel et al. (1991) found that bacterial strains isolated from serpentine soils tolerated up to $10-20 \mathrm{mM} \mathrm{Ni}$ (in the culture medium), whereas strains from other soil types tolerated only $1 \mathrm{mM} \mathrm{Ni}$. Turgay et al. (2012) reported that bacterial strains, isolated from Turkish serpentine soils, could tolerate up to $34 \mathrm{mM} \mathrm{Ni}$ in the growth medium. Furthermore, as described above, the rhizosphere bacterial communities associated with Ni-hyperaccumulating plants have been shown to differ from those of non-accumulating plants growing at the same site or of non-vegetated soil, but are also known to host a higher number of Ni-tolerant bacteria (Schlegel et al. 1991; Mengoni et al. 2001; Abou-Shanab et al. 2003b; Becerra-Castro et al. 2009; ÁlvarezLópez et al. 2016a). Schlegel et al. (1991) reported a higher occurrence of Ni-resistant bacteria in soil samples collected with increasing proximity to the Ni-hyperaccumulating tree Sebertia (= Pycnandra) acuminata. Mengoni et al. (2001) also found a higher proportion of Ni-resistant cfu in proximity to the Ni-hyperaccumulator $A$. bertolonii than in non-vegetated soil. These authors observed simultaneous resistance to a set of metals and highest resistance from isolates of the rhizosphere. Becerra-Castro et al. (2009) found higher proportions of Ni-tolerant bacteria in the rhizosphere of A. serpyllifolium ssp. lusitanicum. This selective enrichment of Ni-tolerant bacteria in the rhizosphere was correlated with an increase in soil Ni availability (Becerra-Castro et al. 2009). Álvarez-López et al. (2016a) confirmed higher densities of Ni-tolerant bacteria associated with the Ni-hyperaccumulators $A$. serpyllifolium ssp. lusitanicum and A. serpyllifolium ssp. malacitanum, but observed significant differences in this selective enrichment amongst different plant populations across the Iberian Peninsula.

The screening of bacterial isolates associated with metal (hyper)accumulating plants has led to the identification of candidate inoculants for application in phytomining. Bacterial strains are commonly characterized for the presence of PGP traits such as the capacity to produce phytohormones (IAA), to solubilize inorganic $\mathrm{P}$ or $\mathrm{K}$, to fix atmospheric $\mathrm{N}_{2}$, to release siderophores, or for their ACC activity. Most bioaugmentation studies have evaluated the effects of re-inoculating host plants with their associated isolates (Abou-Shanab et al. 2003a; Abou-Shanab et al. 2006; Li et al. 2007; Cabello-Conejo et al. 2014). However, the specificity of these plant-bacterial combinations is not always clear, and some inoculants have been shown to have beneficial effects on a wide range of plant hosts (Grandlic et al. 2008; Ma et al. 2011; Becerra-Castro et al. 2012). The main objective of these studies has been to improve metal yields during phytoextraction. In this technique, a simple improvement in biomass can result in an increase in overall trace element removal (Sessitsch et al. 2013). In a metaanalysis carried out by Sessitsch et al. (2013), including results from more than 70 publications and 738 individual cases, the authors found that bacterial inoculation was generally more successful in promoting plant growth and biomass production ( $60 \%$ of total cases analyzed) than in influencing shoot trace elements accumulation (only $30 \%$ of cases showed a significant increase in shoot trace elements concentration, and $16 \%$ a decrease in trace elements concentration).

Ma et al. (2009a, b) found that inoculation with PGP rhizobacteria (Psychrobacter sp. SRA1, Bacillus cereus SRA10 and Achromobacter xylosoxidans strain Ax10) improved the growth of Brassica juncea and B. oxyrrhina, enhanced soil Ni availability, and increased Ni accumulation in both species. Similarly, Rajkumar and Freitas (2008b) observed that inoculation with the PGP rhizobacterial strains Pseudomonas sp. PsM6 and P. jessenii PjM15 isolated from a serpentine soil in $R$. communis caused an increase in above-ground biomass, mainly due to IAA production and phosphate solubilization, and consequently enhanced phytoextraction efficiency. Zaidi et al. (2006) demonstrated that inoculation with Bacillus subtilis strain SJ-101 not only stimulated the growth of, and $\mathrm{Ni}$ accumulation in, Brassica juncea, but also protected the plant from Ni toxicity. Various authors also reported increases in 
Ni uptake by $B$. juncea and other non-hyperaccumulating plant species (B. napus, Ricinus communis, Poa pratensis, etc.) after bacterial inoculation (Rajkumar and Freitas 2008a, b; Kumar et al. 2009; Gullap et al. 2014). With regard to Ni-hyperaccumulating species, Abou-Shanab et al. (2003b) showed that the strain Microbacterium arabinogalactanolyticum isolated from the rhizosphere of A. murale significantly increased availability of $\mathrm{Ni}$ in the soil and enhanced $\mathrm{Ni}$ accumulation by A. murale. In agreement with these results, a posterior study with $A$. murale grown in artificially Ni-polluted soils demonstrated that inoculation with selected rhizobacteria strains increased $\mathrm{Ni}$ extraction from the soil and $\mathrm{Ni}$ uptake by A. murale (Abou-Shanab et al. 2006). These authors considered the presence of such rhizobacteria to be an important factor that influenced metal hyperaccumulation. BecerraCastro et al. (2013) used two strains of Arthrobacter (SBA82 and LA44) harbouring several plant growth-promoting characteristics are able to mobilize $\mathrm{Ni}$ from serpentine rock, as an inoculum for $A$. serpyllifolium ssp. malacitanum grown in ultramafic soil, and observed an increase in plant biomass and shoot Ni concentrations. Durand et al. (2016) isolated plant growth-promoting rhizobacteria from the rhizosphere soil of two hyperaccumulator plant associations: $B$. tymphaea-N. tymphaea (NB) and B. tymphaea-A. murale (AB), both being characteristic of a serpentine outcrop in Greece. The screening of the isolates revealed two PGPR strains (AB30 and NB24) that were affiliated to Variovorax paradoxus and that were used to inoculate the same plant associations growing in mesocosms. Biomass (root and shoot), shoot Ni uptake, and Ni removal by the B. tymphaea-N. tymphaea plant association inoculated with strain NB24 was significantly higher than that of the respective non-inoculated association.

Benefits to plants of mycorrhizal inoculation in highly stressed and nutrient-poor environments are well documented. Inoculation with arbuscular mycorrhizae in trace elementspolluted mine tailings has proven particularly effective in enhancing plant survival and performance during restoration (Orłowska et al. 2011; Kohler et al. 2015; Maltz and Treseder 2015). However, fewer studies have found inoculating with mycorrhizal fungi species or strains to enhance metal uptake and accumulation. In fact, until the early 2000s, hyperaccumulating plants were generally considered non-mycorrhizal (Gonçalves et al. 1997; Leyval et al. 1997; Pawlowska et al. 2000). Since then, several studies have found that hyperaccumulators can form symbioses with arbuscular mycorrhizal fungi (AMF). Pteris vitatta, an As-hyperaccumulating fern, tended to show higher mycorrhizal colonization on As-polluted soil. Leung et al. (2007) suggested that enhanced $\mathrm{P}$ uptake could be linked to increased As absorption and transport. Mycorrhizal colonisation has been observed in Thlaspi praecox, a Cd- and Zn-hyperaccumulator of the Brassicaceae family (generally considered to be non-mycorrhizal) growing on metal-polluted soil in Slovenia (Vogel-Mikus et al. 2005). Berkheya coddii was the first Ni-hyperaccumulating plant in which the presence of arbuscular mycorrhizal (AM) symbiosis was reported (Turnau and Mesjasz-Przybylowicz 2003). Arbuscular mycorrhizal fungi (AMF) isolated from serpentine soil significantly enhanced growth and survival of the Ni-hyperaccumulator $B$. coddii when growing in the same soil (Orłowska et al. 2011). AMF inoculation reduced shoot and root Ni concentrations, however, and owing to the higher biomass the total $\mathrm{Ni}$ yield was up to 20 times greater in mycorrhizal plants compared to the non-mycorrhizal ones. The authors proposed that AMF enhancement of $\mathrm{Ni}$ uptake may help to improve $\mathrm{Ni}$ phytomining techniques.

\section{$5 \quad$ Improving Soil Metal Removal Using Metal-Mobilizing Microbial Strains}

Metal-hyperaccumulating plant species have an extraordinary capacity for trace metal accumulation. Many authors have considered the possibility that such species actively mobilize trace 
elements from non-labile soil metal pools, as a means of increasing the labile concentrations and consequently plant uptake and accumulation. In accordance, several studies have shown a higher labile fraction of hyperaccumulated metals, such as $\mathrm{Ni}$, at the rhizosphere of these plants compared to those of non-accumulating plant species or the surrounding non-vegetated soil (Puschenreiter et al. 2005). However, most authors have concluded that this effect is not a result of specific metal-mobilizing mechanisms employed by hyperaccumulators. It seems more likely, therefore, that the pronounced depletion of trace elements in the rhizosphere, caused by the high rate of uptake of the element from the soil solution, induces their replenishment from the lessmobile fraction to the mobile pools, and maintains a sustained high metal concentration in the soil solution. Root activity of $N$. goesingensis has been proposed to participate in an enhanced dissolution of Ni-bearing minerals, contributing to higher $\mathrm{Ni}$ uptake (Puschenreiter et al. 2005). Similarly, mineralogical studies have shown the presence of smectite in the rhizosphere of A. serpyllifolium ssp. lusitanicum, which was related to a more intense weathering of Ni-rich ferromagnesium minerals (chlorite, serpentine) and an increase in labile $\mathrm{Ni}$ (Kidd et al. 2009). Chardot-Jacques et al. (2013) found that growth of the Ni-hyperaccumulator L. emarginata increased the dissolution of chrysotile (a silicate mineral of the serpentine group with low Ni solubility). These authors suggested that the high $\mathrm{Ni}$ uptake by the plant causes a decrease in water-soluble $\mathrm{Ni}$, which in turn induces chrysotile dissolution. However, whether this phenomenon is plant- or microbially-induced, or the result of complex plant-microbial interactions, is unknown. It is well established that microbial transformation of soil minerals leads to the solubilization of metals together with essential nutrients, and to the modification of their form and distribution in the solid phase (Quantin et al. 2002). Soil metal availability greatly influences the success of phytomining and its long-term sustainability, and bioaugmentation with metal-mobilizing, plant-associated bacteria could enhance the viability of this technique (Kidd et al. 2009).

Microbes are intimately associated with the biogeochemical cycling of metals. Microbial activity can result in metal mobilization or immobilization depending on the mechanism involved and the microenvironment where the organism(s) are located (Violante et al. 2008; Ehrlich and Newman 2009; Gadd 2010) (Fig. 2). Some metal-tolerant bacterial strains associated with (hyper)accumulating plants have been shown to mobilize metals in soils, and consequently increase the phytoavailable metal fraction in the soil, as well as plant uptake and accumulation. Muehe et al. (2015) found Arabidopsis halleri accumulated $100 \%$ more $\mathrm{Cd}$ and $15 \%$ more $\mathrm{Zn}$ when grown on natural Cd-polluted soil than on the same soil that had undergone gamma-irradiation. Gamma irradiation affected neither plant growth nor soil metal availability, but strongly altered the composition and density of the soil microbial community. Bacteria can modify trace elements mobility and bioavailability through several mechanisms: the release of chelating agents (such as organic acids, phenolic compounds, and siderophores), and acidification or redox changes in the rhizosphere (Lloyd 2003; Glick 2010). Sessitsch et al. (2013) reviewed potential mechanisms for microbial effects on bioavailability in the rhizosphere environment. Sorbed, precipitated, and occluded trace elements can be solubilized by acidification, chelation, and ligand-induced dissolution. To date, two groups of bacterially produced natural chelators are known: organic acids and siderophores. Low-molecular mass carboxylic acids can play an important role in chemical attack of minerals, providing protons as well as a metal-chelating anion (Jacobs et al. 2002; Huang et al. 2004; Lian et al. 2008).

Oxalic acid can leach metals such as $\mathrm{Al}$ and Fe that form soluble oxalate complexes (Strasser et al. 1994). Bacteria that produce trace elementchelating organic acids, such as citric, oxalic, or acetic acid, have been shown to mobilize various trace elements in soil (Becerra-Castro et al. 2013). As mentioned above, siderophores form 


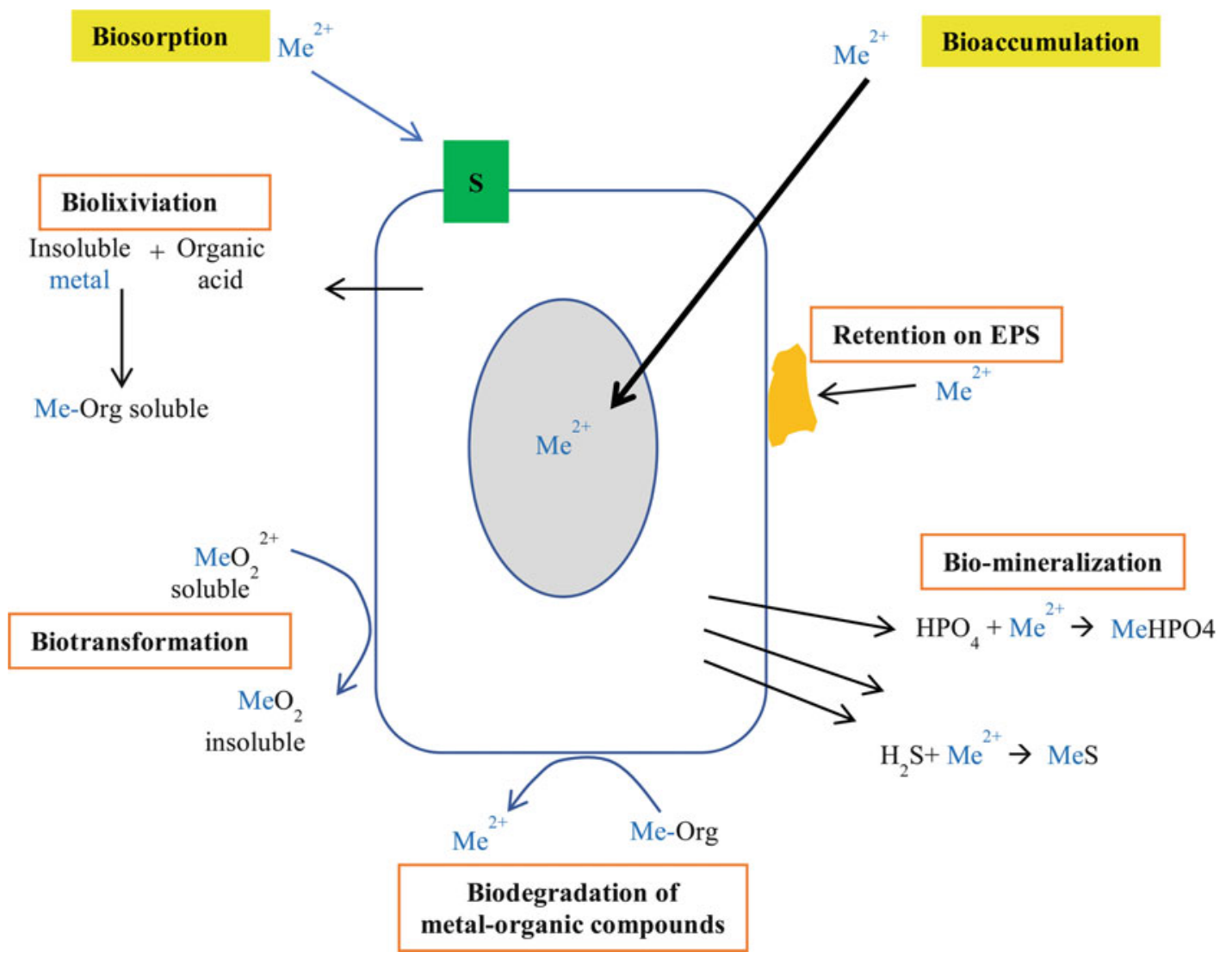

Fig. 2 Interactions between metals and bacteria (adapted from Ledin 2000). S corresponds to the reactive groups present on the bacterial cell wall. $\mathrm{Me}^{2+}$ represents a cation metallic. Org corresponds to an organic compound

high-affinity complexes with $\mathrm{Fe}(\mathrm{III})$, but can also form complexes of lower stability with other trace elements (Al, Cd, $\mathrm{Cu}, \mathrm{Ga}, \mathrm{In}, \mathrm{Ni}, \mathrm{Pb}$ and $\mathrm{Zn}$ ), thus affecting their bioavailability (Schalk et al. 2011; Rajkumar et al. 2012; Sessitsch et al. 2013). Plants can then take up metals from siderophores via various mechanisms, such as chelate degradation, the direct uptake of siderophore-metal complexes, or by a ligand exchange reaction (Schmidt 1999). Braud et al. (2009) reported that inoculating soils with siderophore-producing $P$. aeruginosa significantly increased the concentrations of bioavailable $\mathrm{Cr}$ and $\mathrm{Pb}$ compared with non-inoculated controls. Enhanced heavy metal uptake was correlated with the increased production of siderophores. Siderophore-producing bacteria that are present in metal-polluted or metalenriched soil, and their interaction with hyperaccumulators, could be used in MAP. Several siderophore-producing bacterial strains associated with plants, such as the non-hyperaccumulator Brassica juncea, and the hyperaccumulators $T$. goesingense, $A$. bertolonii, and $A$. murale, have been isolated and characterized from metal-rich soils. They belong to different genera, such as Staphylococcus sp., Microbacterium sp., Pseudomonas sp., Curtobacterium sp., Bacillus sp., Arthrobacter sp., Paenibacillus sp., Leifsonia sp. Methylobacterium mesophilicum, Methylobacterium extorquens, Methylobacterium sp., Burkholderia terricola, Okibacterium fritillariae, Rhodococcus fascians, Rhodococcus sp. (Idris et al. 2004; Barzanti et al. 2007). Becerra-Castro et al. (2013) evaluated the weathering capacities of, and $\mathrm{Ni}$ mobilization by, two rhizobacterial strains associated with the 
Ni-hyperaccumulator A. serpyllifolium ssp. lusitanicum and ssp. malacitanum. A minimal culture medium containing ground ultramafic rock was inoculated with either of two Arthrobacter strains: LA44 (indoleacetic acid [IAA] producer) or SBA82 (siderophore producer, $\mathrm{PO}_{4}$ solubilizer, and IAA producer). Strain LA44 is a more efficient Ni mobilizer, apparently solubilizing $\mathrm{Ni}$ associated with $\mathrm{Mn}$ oxides, and this appeared to be related to the exudation of oxalate. On the other hand, strain SBA82 also led to the release of $\mathrm{Ni}$ and $\mathrm{Mn}$, albeit to a much lower extent. In the latter case, the concurrent mobilization of $\mathrm{Fe}$ and $\mathrm{Si}$ reflects preferential weathering of Fe-oxides and serpentine minerals, possibly related to siderophore production capacity of the strain. However, some conflicting results showed that the presence of siderophore producers decreased the uptake of metals by plants. Siderophores produced by Pseudomonas sp., Serratia marcescens, and Streptomyces sp. had either no effect or negatively affected $\mathrm{Zn}$ and Cd uptake by Salix caprea (Kuffner et al. 2010). These contrasting effects suggest that the mechanisms underlying metal uptake are largely plant dependent, but that the efficiency of siderophore producers to either mobilize or immobilize heavy metals from soils is also dependent on several factors such as the binding form of the heavy metals present, the charge of the siderophores, and the $\mathrm{pH}$ of the soil and its mineral composition and organic content.

The influence of organic matter content in soil on metal availability and uptake by plants has been extensively studied. It was reported that metal adsorption onto soil constituents declined with decreasing organic matter content in soils (Zeng et al. 2011). Moreover, dissolved organic matter (DOC) in soils may increase the mobility and uptake of heavy metals by plant roots (Du Laing et al. 2008). In fact, organic matter decomposition appears to be one of the most important microbial activities in the rhizosphere, and it is well known that microbes, mainly bacteria and fungi, utilize a wide spectrum of organic compounds such as sugars, organic acids, and amino acids to more complex molecules such as cellulose, pectin, lignin, lignocellulose, chitin, and starch. Consequently, organic matter decomposition by soil microorganisms releases metals such as $\mathrm{Fe}, \mathrm{Mn}$, $\mathrm{Zn}, \mathrm{Cu}, \mathrm{Mo}, \mathrm{Ni}, \mathrm{Co}$ and $\mathrm{Se}$, which are typically found in the tissues of organisms.

\section{$6 \quad$ Final Remarks and Future Directions}

It seems clear that the rhizosphere microbiome plays an important role in plant trace elements bioaccumulation, given experimental evidence suggesting that by reshaping this microbiome we can further enhance the efficiency of phytoextraction and phytomining. However, the efficacy of plant-associated bioinoculants is dependent on a complex array of interacting factors: plant-microbe specificity, soil type and properties, trace elements concentration and type (mono- or poly-metallic), proliferation and survival of the inoculant, etc. Moreover, from the literature it can be seen that inoculation methods differ greatly among studies (inoculation of seed/ plant/soil, frequency/timing of inoculation events, bacterial cellular densities, etc.), and these aspects are likely to influence whether or not a beneficial microbially induced effect is observed.

Bioaugmentation can be challenged by the strong competition encountered in the soil when a selected microbe is introduced. Also, the selected host plant species may not necessarily be compatible with the inoculated bacterial or fungal strain, since these are not naturally selected for by the host (Thijs et al. 2016). The importance of rhizosphere competence or effective root colonization in beneficial plant-microbe interactions is underlined by several studies as contributing to the success of bioaugmentation (Lugtenberg and Dekkers 1999). Moreover, inoculation methods should be optimised in orderoptimized to enhance the success of the introduced microorganisms (Álvarez-López et al. 2016b). Pereira et al. (2015) and ÁlvarezLópez et al. (2016b) recently showed that the size of the inoculum applied in the soil rhizosphere, and the mode of application (seed or soil 
inoculation), are important factors that should be taken into account when planning MAP strategies. Endophytes do not have to compete with the large abundance and diversity of soil microorganisms, which may enhance their chances of establishing a stable and active population. To date, the field of MAP has focused on the use of individual bioinoculants. However, promising results have been found when using mixtures or consortia of different PGP-strains with complementary actions. Visioli et al. (2015) reported that co-inoculating the Ni-hyperaccumulator Noccaea caerulescens, when growing in serpentine soil with two root endophytes belonging to the Arthrobacter and Microbacterium genera, had a more positive effect on plant growth, soil $\mathrm{Ni}$ removal, and $\mathrm{Ni}$ translocation, than when inoculated individually. Both strains were strong IAA producers and presented ACC deaminase activity. Moreira et al. (2016) showed the benefits of combined inoculation of AMF and PGPR for the growth of maize as an 'energy-crop' in metal-polluted soils and their potential application in phytomanagement strategies.

Ultramafic rocks occupy $<1 \%$ of Earth's land surface and these outcrops have the potential to provide multiple ecosystem services and contribute to producing renewable raw materials and energy (i.e. agromining). In the same way, polluted soils are an ever-increasing environmental concern due to increased industrialization. Phytoremediation coupled with bioaugmentation could be a solution towards the recovering soil quality, underlining the role of the rhizosphere and microbes associated with hyperaccumulator plants in metal accumulation.

\section{References}

Aboudrar W, Schwartz C, Benizri E, Morel JL, Boularbah A (2007) Microbial diversity as affected by the rhizosphere of the hyperaccumulator Thlaspi caerulescens under natural conditions. Int $\mathrm{J}$ Phytoremediation 9:41-52

Aboudrar W, Schwartz C, Morel JL, Boularbah A (2013) Effect of nickel-resistant rhizosphere bacteria on the uptake of nickel by the hyperaccumulator Noccaea caerulescens under controlled conditions. J Soils Sediments 13:501-507

Abou-Shanab RI, Delorme TA, Angle JS, Chaney RL, Ghanem K, Moawad H, Ghozlan HA (2003a) Phenotypic characterization of microbes in the rhizosphere of Alyssum murale. Int J Phytoremediation 5:367-379

Abou-Shanab RA, Angle JS, Delorme TA, Chaney RL, van Berkum P, Moawad H, Ghanem K, Ghozlan HA (2003b) Rhizobacterial effects on nickel extraction from soil and uptake by Alyssum murale. New Phytol 158:219-224

Abou-Shanab R, Angle J, Chaney R (2006) Bacterial inoculants affecting nickel uptake by Alyssum murale from low, moderate and high Ni soils. Soil Biol Biochem 38:2882-2889

Abou-Shanab RI, van Berkum P, Angle JS (2007) Heavy metal resistance and genotypic analysis of metal resistance genes in gram-positive and gram-negative bacteria present in Ni-rich serpentine soil and in the rhizosphere of Alyssum murale. Chemosphere 68:360-367

Aislabie J, Deslippe JR (2013) Soil microbes and their contribution to soil services. In: Dymond JR (ed) Ecosystem services in New Zealand-conditions and trends. Manaaki Whenua Press, Lincoln, New Zealand, pp 112-161

Álvarez-López V, Prieto-Fernández Á, Becerra-Castro C, Monterroso C, Kidd PS (2016a) Rhizobacterial communities associated with the flora of three serpentine outcrops of the Iberian Peninsula. Plant Soil 403:233-252

Álvarez-López V, Prieto-Fernández Á, Janssen J, Herzig R, Vangronsveld J, Kidd PS (2016b) Inoculation methods using Rhodococcus erythropolis strain P30 affects bacterial assisted phytoextraction capacity of Nicotiana tabacum. Int $\mathrm{J}$ Phytoremediation 18:406-415

Azcón R, Medina A, Roldán A, Biró B, Vivas A (2009) Significance of treated agrowaste residue and autochthonous inoculates (arbuscular mycorrhizal fungi and Bacillus cereus) on bacterial community structure and phytoextraction to remediate soils contaminated with heavy metals. Chemosphere 75:327-334

Badri DV, Chaparro JM, Zhang R, Shen Q, Vivanco JM (2013) Application of natural blends of phytochemicals derived from the root exudates of Arabidopsis to the soil reveal that phenolic-related compounds predominantly modulate the soil microbiome. J Biol Chem 288:4502-4512

Bandick AK, Dick RP (1999) Field management effects on enzyme activities. Soil Biol Biochem 31:1471-1479

Bani A, Echevarria G, Sulçe S, Morel JL (2015) Improving the agronomy of Alyssum murale for extensive phytomining: a five-year field study. Int J Phytoremediation 17:117-127

Banowetz GM, Whittaker GW, Dierksen KP, Azevedo MD, Kennedy AC, Griffith SM, Steiner JJ (2006) Fatty acid methyl ester analysis to identify sources of soil in surface water. J Environ Qual 35:133-140 
Barzanti R, Ozino F, Bazzicalupo M, Gabbrielli R, Galardi F, Gonnelli C, Mengoni A (2007) Isolation and characterization of endophytic bacteria from the nickel hyperaccumulator plant Alyssum bertolonii. Microb Ecol 53:306-316

Baudoin E, Benizri E, Guckert A (2001) Metabolic structure of bacterial communities from distinct maize rhizosphere compartments. Eur J Soil Biol 37:85-93

Baudoin E, Benizri E, Guckert A (2002) Impact of growth stages on bacterial community structure along maize roots by metabolic and genetic fingerprinting. Appl Soil Ecol 19:135-145

Baudoin E, Benizri E, Guckert A (2003) Impact of artificial root exudates on the bacterial community structure in bulk soil and maize rhizosphere. Soil Biol Biochem 35:1183-1192

Beattie GA (2007) Plant-associated bacteria: survey, molecular phylogeny, genomics and recent advances. In: Gnanamanickam SS (ed) Plant-associated bacteria. Springer, Dordrecht, pp 1-56

Becerra-Castro C, Monterroso C, García-Lestón M, Prieto-Fernández A, Acea MJ, Kidd PS (2009) Rhizosphere microbial densities and trace metal tolerance of the nickel hyperaccumulator Alyssum serpyllifolium subsp. lusitanicum. Int $\mathrm{J}$ Phytoremediation 11:525-541

Becerra-Castro C, Monterroso C, Prieto-Fernández Á, Rodríguez-Lamas L, Loureiro-Viñas M, Acea MJ, Kidd PS (2012) Pseudometallophytes colonising $\mathrm{Pb} / \mathrm{Zn}$ mine tailings: a description of the plantmicroorganism-rhizosphere soil system and isolation of metal-tolerant bacteria. J Hazard Mater 217-218:350-359

Becerra-Castro C, Kidd P, Kuffner M, PrietoFernández A, Hann S, Monterroso C, Sessitsch A, Wenzel W, Puschenreiter M (2013) Bacterially induced weathering of ultramafic rock and its implications for phytoextraction. Appl Environ Microbiol 79:5094-5103

Belimov AA, Hontzeas N, Safronova VI, Demchinskaya SV, Piluzza G, Bullitta S, Glick BR (2005) Cadmiumtolerant plant growth-promoting bacteria associated with the roots of Indian mustard (Brassica juncea L. Czern.) Soil Biol Biochem 37:241-250

Bending GD, Turner MK, Jones JE (2002) Interaction between crop residue and organic matter quality and the functional diversity of soil microbial communities. Soil Biol Biochem 34:1073-1082

Benizri E, Nguyen C, Piutti S, Slezack-Deschaumes S, Philippot L (2007) Additions of maize root mucilage to soil changed the structure of the bacterial community. Soil Biol Biochem 39:1230-1233

Berg J, Brandt KK, Al-Soud WA, Holm PE, Hansen LH, Sørensen SJ, Nybroea O (2012) Selection for $\mathrm{Cu}$-tolerant bacterial communities with altered composition, but unaltered richness, via long-term $\mathrm{Cu}$ exposure. Appl Environ Microbiol 78:7438-7446

Blom D, Fabbri C, Connor EC, Schiestl FP, Klauser DR, Boller T, Eberl L, Weisskopf L (2011) Production of plant growth modulating volatiles is widespread among rhizosphere bacteria and strongly depends on culture conditions. Environ Microbiol 13:3047-3058

Boominathan R, Doran P (2003) Cadmium tolerance and antioxidative defences in hairy roots of the cadmium hyperaccumulator, Thlaspi caerulescens. Biotechnol Bioeng 83:158-167

Bordez L, Jourand P, Ducousso M, Carriconde F, Cavaloc Y, Santini S, Claverie JM, Wantiez L, Leveau A, Amir H (2016) Distribution patterns of microbial communities in ultramafic landscape: a metagenetic approach highlights the strong relationships between diversity and environmental traits. Mol Ecol 25:2258-2272

Braud A, Jézéquel K, Bazot S, Lebeau T (2009) Enhanced phytoextraction of an agricultural $\mathrm{Cr}-$ and $\mathrm{Pb}$-contaminated soil by bioaugmentation with siderophore-producing bacteria. Chemosphere 74:280-286

Burd GI, Dixon DG, Glick BR (2000) Plant growthpromoting bacteria that decrease heavy metal toxicity in plants. Can J Microbiol 46:237-245

Cabello-Conejo MI, Becerra-Castro C, Prieto-Fernández A, Monterroso C, Saavedra-Ferro A, Mench M, Kidd PS (2014) Rhizobacterial inoculants can improve nickel phytoextraction by the hyperaccumulator Alyssum pintodasilvae. Plant Soil (1-2):35-50

Carrillo-Castañeda G, Juárez Muños J, Peralta-Videa J, Gomez E, Tiemannb K, Duarte-Gardea M, GardeaTorresdey J (2002) Alfalfa growth promotion by bacteria grown under iron limiting conditions. Adv Environ Res 6:391-399

Chaparro J, Sheflin A, Manter D, Vivanco J (2012) Manipulating the soil microbiome to increase soil health and plant fertility. Biol Fertil Soils 48:489-499

Chardot-Jacques V, Calvaruso C, Simon B, Turpault MP, Echevarria G, Morel JL (2013) Chrysotile dissolution in the rhizosphere of the nickel hyperaccumulator Leptoplax emarginata (2013). Environ Sci Technol 47:2612-2620

Compant S, Duffy B, Nowak J, Clément C, Barka EA (2005) Use of plant growth promoting bacteria for biocontrol of plant diseases: principles, mechanisms of action, and future prospects. Appl Environ Microbiol 71:4951-4959

Crowley D, Kraemer SM (2007) Function of siderophores in the plant rhizosphere. In: Pinton R, Varanini Z, Nannipieri P (eds) The rhizosphere: biochemistry and organic substances at the soil-plant interface. Soil-Plant Interface. CRC Press, Boca Raton, FL

Daghino S, Murat C, Sizzano E, Girlanda M, Perotto S (2012) Fungal diversity is not determined by mineral and chemical differences in serpentine substrates. PLoS One 7(9):e44233

De Souza M, Huang C, Chee N, Terry N (1999) Rhizosphere bacteria enhance the accumulation of selenium and mercury in wetland plants. Planta 209:259-263

De-la-Peña C, Víctor M, Loyola-Vargas ML (2014) Biotic interactions in the rhizosphere: a diverse 
cooperative enterprise for plant productivity. Plant Physiol 166:701-719

Dell'Amico E, Cavalca L, Andreoni V (2008) Improvement of Brassica napus growth under cadmium stress by cadmium-resistant rhizobacteria. Soil Biol Biochem 40:74-84

DeSantis T, Brodie EL, Moberg J, Zubieta I, Piceno Y, Andersen G (2007) High-density universal 16S rRNA microarray analysis reveals broader diversity than typical clone library when sampling the environment. Microb Ecol 53:371-383

Dick RP (1997) Soil enzyme activities as integrative indicators of soil health. In: Pankhurst CE, Doube BM, Gupta VVSR (eds) Biological indicators of soil health. CAB International, Wallingford, pp 121-156

Doelman P (1985) Resistance of soil microbial communities to heavy metals. In: Jensen $\mathrm{V}$, Kjøller A, Sørensen LH (eds) Microbial communities in soils. Elsevier, London, pp 369-384

Dominati E, Patterson M, MacKay A (2010) A framework for classifying and quantifying natural capital and ecosystem services of soils. Ecol Econ 69:1858-1868

Du Laing G, De Vos R, Vandecasteele B, Lesage E, Tack FMG, Verloo MG (2008) Effect of salinity on heavy metal mobility and availability in intertidal sediments of the Scheldt estuary. Estuar Coast Shelf Sci 77:589-602

Duca D, Lorv J, Patten CL, Rose D, Glick BR (2014) Indole-3-acetic acid in plant-microbe interactions. A Van Leeuw J Microb 1-41

Duineveld BM, Kowalchuk GA, Keijzer A, van Elsas JD, van Veen JA (2001) Analysis of bacterial communities in the rhizosphere of Chrysanthemum via Denaturing Gradient Gel Electrophoresis of PCR-amplified 16S rRNA as well as DNA fragments coding for $16 \mathrm{~S}$ rRNA. Appl Environ Microbiol 67:172-178

Duponnois R, Kisa M, Assigbetse K, Prin Y, Thioulouse J, Issartel M, Moulin P, Lepage M (2006) Fluorescent pseudomonads occuring in Macrotermes subhyalinus mound structures decrease $\mathrm{Cd}$ toxicity and improve its accumulation in sorghum plants. Sci Total Environ 370:391-400

Durand A, Piutti S, Rue M, Morel JL, Echevarria G, Benizri E (2016) Improving nickel phytoextraction by co-cropping hyperaccumulator plants inoculated by Plant Growth Promoting Rhizobacteria. Plant Soil 399:179-192

Egamberdieva D, Renella G, Wirth S, Islam R (2011) Enzyme activities in the rhizosphere of plants. In: Shukla G, Varma A (eds) Soil enzymology, soil biology, vol 22. Springer, Berlin, Heidelberg. doi:10. 1007/978-3-642-14225-3_8

Ehrlich HL, Newman DK (2009) Geomicrobiology, 5th edn. CRC Press, Taylor \& Francis, Boca Raton, FL

Ellis RJ, Morgan P, Weightman AJ, Fry JC (2003) Cultivation-dependent and -independent approaches for determining bacterial diversity in heavy-metalcontaminated soil. Appl Environ Microbiol $6: 3223-3230$
Epelde L, Becerril JM, Hernández-Allica J, Barrutia O, Garbisu C (2008) Functional diversity as indicator of the recovery of soil health derived from Thlaspi caerulescens growth and metal phytoextraction. Appl Soil Ecol 39:299-310

Epelde L, Mijangos I, Becerril JM, Garbisu C (2009) Soil microbial community as bioindicator of the recovery of soil functioning derived from metal phytoextraction with sorghum. Soil Biol Biochem 41:1788-1794

Farwell AJ, Vesely S, Nero V, Rodriguez H, Shah S, Dixon DG, Glick BR (2006) The use of transgenic canola (Brassica napus) and plant growth-promoting bacteria to enhance plant biomass at a nickelcontaminated field site. Plant Soil 288:309-318

Farwell AJ, Vesely S, Nero V, Rodriguez H, McCormack K, Shah S, Dixon DG, Glick BR (2007) Tolerance of transgenic canola plants (Brassica napus) amended with plant growth-promoting bacteria to flooding stress at a metal-contaminated field site. Environ Pollut 147:540-545

Fritze H, Pennanen T, Vanhala P (1997) Impact of fertilizers on the humus layer microbial community of Scots pine stands growing along a gradient of heavy metal pollution. In: Insam H, Rangger A (eds) Microbial communities. Functional versus structural aspects. Springer, Berlin, pp 68-83

Gadd GM (2010) Metals, minerals and microbes: geomicrobiology and bioremediation. Microbiology 156:609-643

García-Gonzalo P, Pradas del Real AE, Lobo MC, PérezSanz A (2016) Different genotypes of Silene vulgaris (Moench) Garcke grown on chromium-contaminated soils influence root organic acid composition and rhizosphere bacterial communities. Environ Sci Pollut Res 1-12

Garland JL, Mills AL (1991) Classification and characterisation of heterotrophic microbial communities on the basis of patterns of communitylevel-sole-carbon-source-utilization. Appl Environ Microbiol 57:2351-2359

Glick BR (2010) Using soil bacteria to facilitate phytoremediation. Biotechnol Adv 28:367-374

Gołębiewski M, Deja-Sikora E, Cichosz M, Tretyn A, Wróbel B (2014) 16S rDNA pyrosequencing analysis of bacterial community in heavy metals polluted soils. Microb Ecol 67:635-647

Gonçalves SC, Goncalves MT, Freitas H, Martins-Loucao MA (1997) Mycorrhizae in a Portuguese serpentine community. In: Jaffré T, Reeves RD, Becquer T (eds) The ecology of ultramafic and metalliferous areas. Proceedings of the Second International Conference on Serpentine Ecology. Centre ORSTOM de Nouméa, New Caledonia, pp 87-89

Grandlic CJ, Mendez MO, Chorover J, Machado B, Maier RM (2008) Plant growth promoting bacteria for phytostabilization of mine tailings. Environ Sci Technol 42:2079-2084

Grayston SJ, Wang S, Campbell CD, Edwards AC (1998) Selective influence of plant species on microbial 
diversity in the rhizosphere. Soil Biol Biochem 30:369-378

Gullap MK, Dasci M, Erkovan HI, Koc A, Turan M (2014) Plant Growth-Promoting Rhizobacteria (PGPR) and phosphorus fertilizer-assisted phytoextraction of toxic heavy metals from contaminated soils. Commun Soil Sci Plant Anal 45:2593-2606

Guo J, Tang S, Ju X, Ding Y, Liao S, Song N (2011) Effects of inoculation of a plant growth promoting rhizobacterium Burkholderia sp. D54 on plant growth and metal uptake by a hyperaccumulator Sedum alfredii Hance grown on multiple metal contaminated soil. World J Microbiol Biotechnol 27:2835-2844

Gürtler V, Stanisich VA (1996) New approaches to typing and identification of bacteria using the 16S-23S rDNA spacer region. Microbiology 142:3-16

Hagmann DF, Goodey NM, Mathieu C, Evans J, Aronson MFJ, Gallagher F, Krumins JA (2015) Effect of metal contamination on microbial enzymatic activity in soil. Soil Biol Biochem 91:291-297

Haslmayr HP, Meißner S, Langella F, Baumgarten A, Geletneky J (2014) Establishing best practice for microbially aided phytoremediation. Environ Sci Pollut Res 21:6765-6774

Hattori H (1989) Influence of cadmium on decomposition of sewage sludge and microbial activities in soils. Soil Sci Plant Nutr 35:289-299

He LY, Chen ZJ, Ren G-D, Zhang Y-F, Qian M, Sheng $\mathrm{X}-\mathrm{F}$ (2009) Increased cadmium and lead uptake of a cadmium hyperaccumulator tomato by cadmiumresistant bacteria. Ecotoxicol Environ Saf 72:1343-1348

He LY, Zhang YF, Ma HY, LN S, Chen ZJ, Wang QY, Qian M, Sheng XF (2010a) Characterization of copper-resistant bacteria and assessment of bacterial communities in rhizosphere soils of copper-tolerant plants. Appl Soil Ecol 44:49-55

He CQ, Tan G, Liang X, Du W, Chen Y, Zhi G, Zhu Y (2010b) Effect of Zn-tolerant bacterial strains on growth and $\mathrm{Zn}$ accumulation in Orychophragmus violaceus. Appl Soil Ecol 44:1-5

Herrera A, Héry M, Stach JEM, Jaffré T, Normand P, Navarro E (2007) Species richness and phylogenetic diversity comparisons of soil microbial communities affected by nickel-mining and revegetation efforts in New Caledonia. Eur J Soil Biol 43:130-139

Héry M, Nazaret S, Jaffré T, Normand P, Navarro E (2006) Adaptation to nickel spiking of bacterial communities in neocaledonian soils. Environ Microbiol 5:3-12

Hiltner L (1904) Über neuer Erfahrungen und Probleme auf dem Gebiet der Bodenbakteriologie unter besonderer Nerücksichtingung der Gründüngung und Brache. Arbeiten aus dem Deutschen Landwirtschafts Geselschaft 98:59-78

Hinsinger P, Plassard C, Jaillard B (2006) Rhizosphere: a new frontier for soil biogeochemistry. J Geochem Explor 88:210-213
Hu Q, Qi HY, Zeng JH, Zhang HX (2007) Bacterial diversity in soils around a lead and zinc mine. J Environ Sci 19:74-79

Huang PM, Wang MC, Wang MK (2004) Mineralorganic-microbial interactions. In: Hillel D, Rosenzweig C, Powlson DS, Scow KM, Singer MJ, Sparks DL, Hatfield J (eds) Encyclopedia of soils in the environment. Elsevier, Amsterdam, pp 486-499

Hussein H (2008) Optimization of plant-bacteria complex for phytoremediation of contaminated soils. Int J Bot 4:437-443

Idris R, Trifonova R, Puschenreiter M, Wenzel WW, Sessitsch A (2004) Bacterial communities associated with flowering plants of the $\mathrm{Ni}$ hyperaccumulator Thlaspi goesingense. Appl Environ Microbiol 70:2667-2677

Jacobs H, Boswell GP, Ritz K, Davidson FA, Gadd GM (2002) Solubilization of metal phosphates by Rhizoctonia solani. Mycol Res 106:1468-1479

Janssen J, Weyens N, Croes S, Beckers B, Meiresonne L, Van Peteghem P, Carleer R, Vangronsveld J (2015) Phytoremediation of metal contaminated soil using willow: exploiting plant associated bacteria to improve biomass production and metal uptake. Int $\mathbf{J}$ Phytoremediation 17:1123-1136

Jiang CY, Sheng XF, Qian M, Wang QY (2008) Isolation and characterization of a heavy metal resistant Burkholderia sp. from heavy metal-contaminated paddy field soil and its potential in promoting plant growth and heavy metal accumulation in metalpolluted soil. Chemosphere 72:157-164

Kandeler E, Tscherko D, Bruce KD, Stemmer M, Hobbs PJ, Bardgett RD, Amelung W (2000) The structure and function of the soil microbial community in microhabitats of a heavy metal polluted soil. Biol Fertil Soils 32:390-400

Kapulnik Y, Douds D (2000) Arbuscular Mycorrhizas: physiology and function. Kluwer Academic, Dordrecht, The Netherlands, $384 \mathrm{pp}$

Khan S, El-Latif Hesham A, Qiao M, Rehman S, He JZ (2010) Effects of $\mathrm{Cd}$ and $\mathrm{Pb}$ on soil microbial community structure and activities. Environ Sci Pollut Res 17:288-296

Kidd P, Barceló J, Bernal MP, Navari-Izzo F, Poschenrieder C, Shilev S, Clemente R, Monterroso C (2009) Trace element behaviour at the root-soil interface: implications in phytoremediation. Environ Exp Bot 67:243-259

Kinnersley AM (1993) The role of phytochelates in plant growth and productivity. Plant Growth Regul 12:207-218

Kirk JL, Beaudette LA, Hart M, Moutoglis P, Klironomos JN, Lee H, Trevors JT (2004) Methods of studying soil microbial diversity. J Microbiol Methods 58:169-188

Knight BP, McGrath SP, Chaudri AM (1997) Biomass carbon measurements and substrate utilization patterns of microbial populations from soils amended 
with cadmium, copper, or zinc. Appl Environ Microbiol 63:39-43

Kohler J, Caravaca F, Azcón R, Díaz G, Roldán A (2015) The combination of compost addition and arbuscular mycorrhizal inoculation produced positive and synergistic effects on the phytomanagement of a semiarid mine tailing. Sci Total Environ 514:42-48

Kozdrój J, van Elsas JD (2001a) Structural diversity of microorganisms in chemically perturbed soil assessed by molecular and cytochemical approaches. J Microbiol Methods 43:197-212

Kozdrój J, van Elsas JD (2001b) Structural diversity of microbial communities in arable soils of a heavily industrialised area determined by PCR-DGGE fingerprinting and FAME profiling. Appl Soil Ecol $17: 31-42$

Krumins JA, Goodey NM, Gallagher FJ (2015) Plant-soil interactions in metal contaminated soils. Soil Biol Biochem 80:224-231

Kuffner M, Puschenreiter M, Wieshammer G, Gorfer M, Sessitsch A (2008) Rhizosphere bacteria affect growth and metal uptake of heavy metal accumulating willows. Plant Soil 304:35-44

Kuffner M, De Maria S, Puschenreiter M, Fallmann K, Wieshammer G, Gorfer M, Strauss J, Rivelli AR, Sessitsch A (2010) Culturable bacteria from $\mathrm{Zn}$ - and Cd-accumulating Salix caprea with differential effects on plant growth and heavy metal availability. J Appl Microbiol 108:1471-1484

Kumar KV, Singh N, Behl H, Srivastava S (2008) Influence of plant growth promoting bacteria and its mutant on heavy metal toxicity in Brassica juncea grown in fly ash amended soil. Chemosphere 72:678-683

Kumar KV, Srivastava S, Singh N, Behl HM (2009) Role of metal resistant plant growth promoting bacteria in ameliorating fly ash to the growth of Brassica juncea. J Hazard Mater 170:51-57

Kuperman RG, Carreiro MM (1997) Soil heavy metal concentrations, microbial biomass and enzyme activities in a contaminated grassland ecosystem. Soil Biol Biochem 29:179-190

Kurek E, Jaroszuk-Scisel J (2003) Rye (Secale cereale) growth promotion by Pseudomonas fluorescens strains and their interactions with Fusarium culmorum under various soil conditions. Biol Control 26:48-56

Lebeau T, Braud A, Jezequel K (2008) Performance of bioaugmentation-assisted phytoextraction applied to metal contaminated soils: a review. Environ Pollut 153:497-522

Lemanceau P, Maurhofer M, Défago G (2007) Contribution of studies on suppressive soils to the identification of bacterial biocontrol agents and to the knowledge of their modes of action. In: Gnanamanickam SS (ed) Plant-associated bacteria. Springer, The Netherlands, pp 231-267

Leung HM, Ye ZH, Wong MH (2007) Survival strategies of plants associated with arbuscular mycorrhizal fungi on toxic mine tailings. Chemosphere 66:905-915
Leyval C, Turnau K, Haselwandter K (1997) Effect of heavy metal pollution on mycorrhizal colonization and function: physiological, ecological and applied aspects. Mycorrhiza 7:139-153

Li Z, Xu J, Tang C, Wu J, Muhammad A, Wan H (2006) Application of $16 \mathrm{~S}$ rDNA-PCR amplification and DGGE fingerprinting for detection of shift in microbial community diversity in $\mathrm{Cu}-, \mathrm{Zn}-$, and Cd-contaminated paddy soils. Chemosphere 62:1374-1380

Li WC, Ye ZH, Wong MH (2007) Effects of bacteria on enhanced metal uptake of the $\mathrm{Cd} /$ Zn-hyperaccumulating plant, Sedum alfredii. J Exp Bot 58:4173-4182

Lian B, Chen Y, Zhu L, Yang R (2008) Effect of microbial weathering on carbonate rocks. Earth Sci Front 15:90-99

Liang CN, Tabatabai MA (1978) Effects of trace elements on nitrification in soils. J Environ Qual 7:291-293

Lipman CB (1926) The bacterial flora of serpentine soils. J Bacteriol 12:315-318

Lloyd JR (2003) Microbial reduction of metals and radionuclides. FEMS Microbiol Rev 27:411-425

Lodewyckx C, Mergeay M, Vangronsveld J, Clijsters H, Van der Lelie D (2002) Isolation, characterization, and identification of bacteria associated with the zinc hyperaccumulator Thlaspi caerulescens subsp. calaminaria. Int J Phytoremediation 4:101-115

Lucisine P, Echevarria G, Sterckeman T, Vallance J, Rey P, Benizri E (2014) Effect of hyperaccumulating plant cover composition and rhizosphere-associated bacteria on the efficiency of nickel extraction from soil. Appl Soil Ecol 81:30-36

Lugtenberg BJJ, Dekkers LC (1999) What makes Pseudomonas bacteria rhizosphere competent? Environ Microbiol 1:9-13

Ma Y, Rajkumar M, Freitas H (2009a) Improvement of plant growth and nickel uptake by nickel resistantplant-growth promoting bacteria. J Hazard Mater 166:1154-1161

Ma Y, Rajkumar M, Freitas H (2009b) Isolation and characterization of Ni mobilizing PGPB from serpentine soils and their potential in promoting plant growth and $\mathrm{Ni}$ accumulation by Brassica. Chemosphere 75:719-725

Ma Y, Rajkumar M, Freitas H (2009c) Inoculation of plant growth promoting bacterium Achromobacter xylosoxidans strain Ax10 for the improvement of copper phytoextraction by Brassica juncea. J Environ Manag 90:831-837

Ma Y, Prasad MNV, Rajkumar M, Freitas H (2011) Plant growth promoting rhizobacteria and endophytes accelerate phytoremediation of metalliferous soils. Biotechnol Adv 29:248-258

Ma Y, Rajkumar M, Luo Y, Freitas H (2013) Phytoextraction of heavy metal polluted soils using Sedum plumbizincicola inoculated with metal mobilizing Phyllobacterium myrsinacearum RC6b. Chemosphere 93:1386-1392 
Maltz MR, Treseder KK (2015) Sources of inocula influence mycorrhizal colonization of plants in restoration projects: a meta-analysis. Restor Ecol 23:625-634

Mastretta C, Taghavi S, van der Lelie D, Mengoni A, Galardi F, Gonnelli C, Barac T, Boulet J, Weyens N, Vangronsveld J (2009) Endophytic bacteria from seeds of Nicotiana tabacum can reduce cadmium phytotoxicity. Int J Phytoremediation 11:251-267

Mengoni A, Barzanti R, Gonnelli C, Gabbrielli R, Bazzicalupo M (2001) Characterization of nickelresistant bacteria isolated from serpentine soil. Environ Microbiol 3:691-698

Mengoni A, Grassi E, Barzanti R, Biondi EG, Gonnelli C, Kim CK, Bazzicalupo M (2004) Genetic diversity of bacterial communities of serpentine soil and of rhizosphere of the nickel-hyperaccumulator plant Alyssum bertolonii. Microb Ecol 48:209-217

Moreira H, Pereira SIA, Marques APGC, Rangel AOSS, Castro PML (2016) Mine land valorization through energy maize production enhanced by the application of plant growth-promoting rhizobacteria and arbuscular mycorrhizal fungi. Environ Sci Pollut Res 23:6940-6950

Muehe EM, Weigold P, Adaktylou IJ, Planer-Friedrich B, Kraemer U, Kappler A, Behrensa S (2015) Rhizosphere microbial community composition affects cadmium and zinc uptake by the metalhyperaccumulating plant Arabidopsis halleri. Appl Environ Microbiol 81:2173-2181

Muyzer G (1999) Genetic fingerprinting of microbial communities-present status and future perspectives. Methods of microbial community analysis. Proceedings of the 8th international symposium on microbial ecology. Atlantic Canada Society for Microbial Ecology, Halifax, Canada

Nannipieri P, Giagnoni L, Renella G, Puglisi E, Ceccanti B, Masciandaro G, Fornasier F, Moscatelli MC, Marinari S (2012) Soil enzymology: classical and molecular approaches. Biol Fertil Soils 48:743-762

Naseby DC, Lynch JM (2002) Enzymes and microbes in the rhizosphere. In: Burns RG, Dick RP (eds) Enzymes in the environment. Marcel Dekker, New York, pp 109-123

Nguyen C (2003) Rhizodeposition of organic C by plants: mechanisms and controls. Agronomie 23:375-396

Niklinska M, Chodak M, Laskowski R (2006) Pollutioninduced community tolerance of microorganisms from forest soil organic layers polluted with $\mathrm{Zn}$ or $\mathrm{Cu}$. Appl Soil Ecol 32:265-272

Oline DK (2006) Phylogenetic comparisons of bacterial communities from serpentine and nonserpentine soils. Appl Environ Microbiol 72:6965-6971

Orłowska E, Orłowski D, Mesjasz-Przybyłowicz J, Turnau K (2011) Role of mycorrhizal colonization in plant establishment on an alkaline gold mine tailing. Int J Phytoremediation 13:185-205

Pal A, Dutta S, Mukherjee PK, Paul AK (2005) Occurrence of heavy metal-resistance in microflora from serpentine soil of Andaman. J Basic Microbiol 45:207-218

Pal A, Wauters G, Paul AK (2007) Nickel tolerance and accumulation by bacteria from rhizosphere of nickel hyperaccumulators in serpentine soil ecosystem of Andaman, India. Plant Soil 1:37-48

Pawlowska TE, Chaney RL, Chin M, Charvat I (2000) Effects of metal phytoextraction practices on the indigenous community of arbuscular mycorrhizal fungi at a metal contaminated landfill. Appl Environ Microbiol 66:2526-2530

Pereira SIA, Barbosa L, Castro PML (2015) Rhizobacteria isolated from a metal-polluted area enhance plant growth in zinc and cadmiumcontaminated soil. Int $\mathrm{J}$ Environ Sci Technol 12:2127-2142

Pessoa-Filho M, Barreto CC, dos Reis Junior FB, Fragoso RR, Costa FS, Carvalho Mendes I, Rovênia Miranda de Andrade L (2015) Microbiological functioning, diversity, and structure of bacterial communities in ultramafic soils from a tropical savanna. Antonie Van Leeuwenhoek 107:935-949

Puschenreiter M, Schnepf A, Millán MI, Fitz WJ, Horak O, Klepp J, Schrefl T, Lombi E, Wenzel WW (2005) Changes of Ni biogeochemistry in the rhizosphere of the hyperaccumulator Thlaspi goesingense. Plant Soil 271:205-218

Quantin C, Becquer T, Rouiller JH, Berthelin J (2002) Redistribution of metals in a New Caledonia ferralsol after microbial weathering. Soil Sci Soc Am J 66:1797-1804

Raaijmakers JM, Vlami M, de Souza JT (2002) Antibiotic production by bacterial biocontrol agents. Antonie Van Leeuwenhoek Antonie Leeuwenhoek 81:537-547

Rajkumar M, Freitas H (2008a) Effects of inoculation of plant-growth promoting bacteria on $\mathrm{Ni}$ uptake by Indian mustard. Bioresour Technol 99:3491-3498

Rajkumar M, Freitas H (2008b) Influence of metal resistant-plant growth-promoting bacteria on the growth of Ricinus communis in soil contaminated with heavy metals. Chemosphere 71:834-842

Rajkumar M, Nagendran R, Lee KJ, Lee WH, Kim SZ (2006) Influence of plant growth promoting bacteria and $\mathrm{Cr}^{6+}$ on the growth of Indian mustard. Chemosphere 62:741-748

Rajkumar M, Ma Y, Freitas H (2008) Characterization of metal-resistant plant-growth promoting Bacillus weihenstephanensis isolated from serpentine soil in Portugal. J Basic Microbiol 48:500-508

Rajkumar M, Sandhya S, Prasad MNV, Freitas H (2012) Perspectives of plant-associated microbes in heavy metal phytoremediation. Biotechnol Adv 30:1562-1574

Ranjard L, Poly F, Nazaret S (2000) Monitoring complex bacterial communities using culture-independent molecular techniques: application to soil environment. Microbiology 151:167-177

Ranjard L, Echairi A, Nowak V, Lejon DPH, Nouaïm R, Chaussod R (2006) Field and microcosm experiments 
to evaluate the effects of agricultural copper treatment on the density and genetic structure of microbial communities in two different soils. FEMS Microbiol Ecol 58:303-315

Rastogi G, Sani RK (2011) Molecular techniques to assess microbial community structure, function, and dynamics in the environment. In: Ahmad I et al (eds) Microbes and microbial technology, agricultural and environmental applications. Springer, New York, pp 29-57

Renella G, Egamberdiyeva D, Landi L, Mench M, Nannipieri P (2006) Soil microbial activity and hydrolase activity during decomposition of model root exudates released by a model root surface in Cd-contaminated soils. Soil Biol Biochem 38:702-708

Renella G, Zornoza R, Landi L, Mench M, Nannipieri P (2011) Arylesterase activity in trace element contaminated soils. Eur J Soil Sci 62:590-597

Richardson AE, Simpson RJ (2011) Soil microorganisms mediating phosphorus availability update on microbial phosphorus. Plant Physiol 156:989-996

Rue M, Vallance J, Echevarria G, Rey P, Benizri E (2015) Phytoextraction of nickel and rhizosphere microbial communities under mono- or multispecies hyperaccumulator plant cover in a serpentine soil. Aust J Bot 63:92-102

Ryu CM, Farag MA, CH H, Reddy MS, Wei HX, Pare PW, Kloepper JW (2003) Bacterial volatiles promote growth in Arabidopsis. Proc Natl Acad Sci U S A 100:4927-4932

Sanger F, Nicklen S, Coulson AR (1977) DNA sequencing with chain-terminating inhibitors. Proc Natl Acad Sci U S A 74:5463-5467

Schalk IJ, Hannauer M, Braud A (2011) Minireview new roles for bacterial siderophores in metal transport and tolerance. Environ Microbiol 13:2844-2854

Schlegel HG, Cosson JP, Baker AJM (1991) Nickelhyperaccumulating plants provide a niche for nickelresistant bacteria. Bot Acta 104:18-25

Schmidt W (1999) Mechanisms and regulation of reduction-based iron uptake in plants. New Phytol 141:1-26

Sessitsch A, Kuffner M, Kidd P, Vangronsveld J, Wenzel WW, Fallmann K, Puschenreiter M (2013) The role of plant-associated bacteria in the mobilization and phytoextraction of trace elements in contaminated soils. Soil Biol Biochem 60:182-194

Sheng XF, Xia JJ (2006) Improvement of rape (Brassica napus) plant growth and cadmium uptake by cadmium-resistant bacteria. Chemosphere 64:1036-1042

Sheng XF, He L, Wang Q, Ye H, Jiang C (2008a) Effects of inoculation of biosurfactant-producing Bacillus sp. J119 on plant growth and cadmium uptake in a cadmium amended soil. J Hazard Mater 155:17-22

Sheng XF, Xia J-J, Jiang C-Y, He L-Y, Qian M (2008b) Characterization of heavy metal resistant endophytic bacteria from rape (Brassica napus) roots and their potential in promoting the growth and lead accumulation of rape. Environ Pollut 156:1164-1170

Shilev S, Fernández A, Benlloch M, Sancho E (2006) Sunflower growth and tolerance to arsenic is increased by the rhizospheric bacteria Pseudomonas fluorescens. In: Morel JL (ed) Phytoremediation of metal contaminated soils. Springer, The Netherlands, pp 315-326

Smith SE, Read DJ (1996) Mycorrhizal symbiosis, 2nd edn. Academic Press, 605 pp

Sowerby A, Emmett B, Beier C, Tietema A, Penuelas J, Estiarte M, Van Meeteren JMM, Hughes S, Freeman C (2005) Microbial community changes in heathland soil communities along a geographical gradient: interaction with climate change manipulations. Soil Biol Biochem 37:1805-1813

Strasser H, Burgstaller W, Schinner F (1994) High yield production of oxalic acid for metal leaching purposes by Aspergillus niger. FEMS Microbiol Lett 119:365-370

Sun LN, Zhang Y-F, He L-Y, Chen Z-J, Wang Q-Y, Qian M, Sheng X-F (2010) Genetic diversity and characterization of heavy metal-resistant-endophytic bacteria from two copper-tolerant plant species on copper mine wasteland. Bioresour Technol 101:501-509

Tabatabai MA (1994) Soil enzymes. In: Weaver RW, Angle S, Bottomley P (eds) Methods of soil analysis. Part 2, Microbiological and biochemical properties. Soil Science Society of America, Madison, pp $775-833$

Tate RL (2002) Microbiology and enzymology of carbon and nitrogen cycling. In: Burns RG, Dick RP (eds) Enzymes in the environment. Marcel Dekker, New York, pp 227-248

Thangavelu R, Palaniswami A, Ramakrishnan G, Doraiswamy S, Muthukrishana S, Velazhahan R (2001) Involvement of fusaric acid detoxification by Pseudomonas fluorescens strain Pf10 in the biological control of Fusarium wilt of banana caused by Fusarium oxysporum f. sp. cubense. Z. Pflanzenkr. Pflanzenschutz 108:433-445

Thijs S, Sillen W, Rineau F, Weyens N, Vangronsveld J (2016) Towards an enhanced understanding of plantmicrobiome interactions to improve phytoremediation: engineering the metaorganism. Front Microbiol 7:341

Turgay OC, Görmez A, Bilen S (2012) Isolation and characterization of metal resistant-tolerant rhizosphere bacteria from the serpentine soils in Turkey. Environ Monit Assess 184:515-526

Turnau K, Mesjasz-Przybylowicz J (2003) Arbuscular mycorrhiza of Berkheya coddii and other Ni-hyperaccumulating members of Asteraceae from ultramafic soils in South Africa. Mycorrhiza 13:185-190

Van der Heijden MGA, Sanders IR (2002) Mycorrhizal ecology. Springer, Berlin, Germany

van Loon LC, Bakker HM, Pieterse CMJ (1998) Systemic resistance induced by rhizosphere bacteria. Annu Rev Phytopathol 36:453-383 
Vessey JK (2003) Plant growth promoting rhizobacteria as biofertilizers. Plant Soil 255:571-586

Violante A, Huang PM, Gadd GM (eds) (2008) Biophysicochemical processes of heavy metals and metalloids in soil environments. Wiley, Chichester

Visioli G, D'Egidio S, Sanangelantoni AM (2015) The bacterial rhizobiome of hyperaccumulators: future perspectives based on omics analysis and advanced microscopy. Front Plant Sci 5:1-12

Vogel-Mikus K, Drobne D, Regvar M (2005) Zn, Cd and $\mathrm{Pb}$ accumulation and arbuscular mycorrhizal colonisation of pennycress Thlaspi praecox Wulf. (Brassicaceae) from the vicinity of a lead mine and smelter in Slovenia. Environ Pollut 133:233-242

Wang Q, Xiong D, Zhao P, Yu X, Tu B, Wang G (2011) Effect of applying an arsenic-resistant and plant growth-promoting rhizobacterium to enhance soil arsenic phytoremediation by Populus deltoides LH05-17. J Appl Microbiol 111:1065-1074

Warembourg FR (1997) The "rhizosphere effect": a plant strategy for plants to exploit and colonize nutrientlimited habitats. Bocconea 7:187-194

Whiting SN, de Souza MP, Terry N (2001) Rhizosphere bacteria mobilize $\mathrm{Zn}$ for hyperaccumulation by Thlaspi caerulescens. Environ Sci Technol $35: 3144-3150$
Wu SC, Cheung KC, Luo YM, Wong MH (2006) Effects of inoculation of plant growth-promoting rhizobacteria on metal uptake by Brassica juncea. Environ Pollut 140:124-135

Wyszkowska J, Kucharski J, Borowik A, Boros E (2008) Response of bacteria to soil contamination with heavy metals. J Elem 13:443-453

Wyszkowska J, Kucharski M, Kucharski J, Borowik A (2009) Activity of dehydrogenases, catalase and urease in copper polluted soil. J Elem 14:605-617

Xiong J, He Z, Liu D, Mahmood Q, Yang X (2008) The role of bacteria in the heavy metals removal and growth of Sedum alfredii Hance in an aqueous medium. Chemosphere 70:489-494

Yang Q, Tu S, Wang G, Liao X, Yan X (2012) Effectiveness of applying arsenate reducing bacteria to enhance arsenic removal from polluted soils by Pteris vittata L. Int J Phytoremediation 14:89-99

Zaidi S, Usmani S, Singh BR, Musarrat J (2006) Significance of Bacillus subtilis strain SJ-101 as a bioinoculant for concurrent plant growth promotion and nickel accumulation in Brassica juncea. Chemosphere 64:991-997

Zeng F, Ali S, Zhang H, Ouyang Y, Qiu B, Wu F, Zhang $\mathrm{G}$ (2011) The influence of $\mathrm{pH}$ and organic matter content in paddy soil on heavy metal availability and their uptake by rice plants. Environ Pollut 159:84-91 